APLIKASI BISNIS, Volume 7 Nomor 10, Januari 2007

ISSN : $1411-4054$

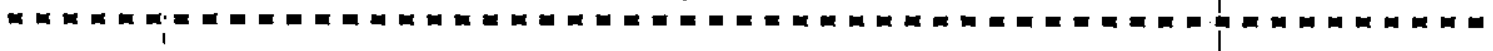

PENGARUH KEADILAN KOMPENSASI TERHADAP KEPUASAN KARYAWAN ADMINISTRASI DI UNIVERSITAS ISLAM INDONESIA YOGYAKARTA

\author{
Oleh: \\ Suhartini \\ Dosen Fakultas Ekonomi Universitas Islam Indonesia \\ Lin Ruhana \\ Alumni Fakultas Ekonomi Universitas Islam Indonesia
}

ABSTRAK

Penelitian ini bertujuan untuk mengetahuii pengaruh pengaruh keadilan kompensasi terhadap kepuasan karyawan administrasi di Universitas Islam Indonesia Yogyakarta. Responden penelitian ini sebanyak 132 orang dengan metode penentuannya menggunakan cluster quota convinience sampling. Pengujian hipotesis menggunakan uji $F$, uji t dan independent sample T-tes. Hasil penelitian menunjukkan bahwa : (1) Secara bersama-sama keadilan individual, keadilan internal dan keadilan eksternal mempengaruhi kepuasan, (2) Keadilan individual merupakan variabel yang paling mempengaruhi kepuasan, dan (3) Tidak ada perbedaan kepuasan antara karyawan administratifstruktural dan pegawai adminstratif non struktural

Kata Kunci : Keadilan Individual, Keadilan Internal, Keadilan Ekstemal, dan Kepuasan Karyawan

Krisis ekonomi yang berkepanjangan menyusul krisis multidimensi seakan membuat masyarakat Indonesia semakin terpuruk. Dalam rangka memperbaiki keadaan ekonomi berbagai perusahaan telah mempersiapkan dan mengadakan program-program yang menarik untuk mempertahankan karyawan yang kompeten, salah satunya adalah program kompensasi.

Masalah kompensasi selalu mendapat perhatian yang besar dari setiap karyawan. Hal itu disebabkan karena kompensasi : (1) merupakan sumber pendapatan, (2) merupakan sumber penerimaan yang diperoleh karena pendidikan dan ketrampilan yang dimilikinya, (3) menunjukkan kontribusi kerja mereka, dan (4) merupakan salah satu elemen kepuasan kerja. Kepuasan terhadap kompensasi yang diterima merupakan elemen utama terciptanya kepuasan kerja karyawan tersebut. Semakin puas seorang karyawan terhadap kompensasi yang diterimanya, maka akan semakin puas karyawan tersebut terhadap pekerjaannya, begitu pula sebaliknya.

Menurut Milkovich \& Newman, konsep keadilan merupakan dasar dalam manajemen kompensasi (Howard \& Miller, 1993:882). Organisasi harus memberi perhatian bagi terciptanya keadilan individual, internal dan eksternal dari kompensasi finansial maupun non-finansial yang diberikan agar mampu menarik, mempertahankan dan memotivasi karyawan untuk mencapai kepuasan dirinya, meningkatkan kinerja dan survive-nya organisasi (Tang, Luk \& Chiu, 2000:43). 


\section{B.HASIL PENELITIAN TERDAHULU}

1. Penelitian Widhiatmoko Setyo Nugroho (2002) yang berjudul "Pengaruh Persepsi Rasa Keadilan Terhadap Kepuasan Kerja Pada Karyawan Administrasi Fakultas Ekonomi Universitas Islam Indonesia, Yogyakarta" Hasil penelitian menunjukkan : (a) Terdapat pengaruh yang signifikan mengenai persepsi rasa keadilan internal dan keadilan eksternal karyawan dalam penerimaan kompensasi secara bersama-sama terhadap kepuasan kerja, (b) Persepsi keadilan internal mempunyai pengaruh yang dominan terhadap kepuasan kerja dan (c) Terdapat perbedaan persepsi rasa keadilan antara karyawan pria dan karyawan wanita dalam penerimaan kompensasi. Persamaan dengan penelitian yang akan dilakukan terdapat pada variabel terikat, sedangkan perbedaan terdapat pada variabel bebas dan lokasi penelitian.

2. Penelitian Djoko Pramono (2004) yang berjudul "Pengaruh Persepsi Kompensasi Yang Adil Terhadap Produktivitas Kerja Pada Karyawan Perusahaan Otobus Jaya Putra Delanggu, Klaten". Hasil penelitian menunjukkan : (a) Ada pengaruh positif dan signifikan antara variabel keadilan terhadap produktivitas kerja secara bersama-sama terhadap karyawan Perusahaan Otobus Jaya Putra Delanggu, Klaten. (b) Keadilan individu mempunyai pengaruh yang dominan terhadap produktivitas kerja. Persamaan dengan penelitian yang akan dilakukan terdapat pada variabel bebasnya, sedangkan perbedaan terdapat pada variabel terikat dan lokasi penelitian.

\section{LANDASAN TEORI}

\section{Keadilan Kompensasi}

Teori keadilan diformulasikan oleh J. Stacy Adam berusaha untuk menerangkan bagaimana proses seorang individu terpuaskan atau tidak terpuaskan terhadap suatu kompensasi. Didalam kompensasi, keadilan memainkan peran utama. Beberapa organisasi berusaha untuk mencapai keadilan yang hendak dicapai melalui program kompensasi yaitu; keadilan internal, eksternal, dan individual (Kanungo, 1992: 82).

a.Keadilan individual (personal equity) tercapai ketika kompensasi yang di terima individu mencerminkan input karyawan. Adil secara individu mencerminkan bahwa karyawan merasa diperlakukan secara wajar dibandingkan dengan rekan sekerja mereka ( Simamora, 2001:553)

b.Keadilan internal (internal equity) tercapai ketika struktur gaji mencerminkan nilai dari pekerjaan. Nilai suatu pekerjaan harus mencerminkan nilai sosial-budaya suatu masyarakat, nilai produk dan jasa yang dibuat, investasi pendidikan, pelatihan, pengalaman kerja, dan posisi pekerjaan di tingkatan organisasi (Wallace and Fay, 1988: 17)

c.Keadilan eksternal (keadilan eksternal) tercapai ketika sistem kompensasi yang diberikan menggambarkan gaji yang relatif sama dengan gaji yang berlaku bagi pekerjaan-pekerjaan yang serupa di pasar tenaga kerja eksternal. Keadilan eksternal dinilai dengan membandingkan pekerjaan yang serupa di antara organisasi-organisasi yang dapat diperbandingkan. 


\section{Kepuasan}

Berdasarkan fulfiliment theory, kepuasan berhasil dicapai apabila suatu kebutuhan telah terpenuhi (Kanungo, 1992: 95). Kepuasan kerja adalah cara pegawai merasakan dirinya atau pekerjaannya. Kepuasan kerja berhubungan dengan variabel-variabel seperti turnover, tingkat absensi, umur, tingkat pekerjaan, dan ukuran organisasi perusahaan (Wexley dan Yukl, 1977:98).

Faktor-faktor yang mempengaruhi kepuasan : (Kanungo, 1992: 104-106);

a. Job Context Factors

Job context factors merupakan faktor-faktor yang terkait dengan pekerjaan seperti gaji, tunjangan, keamanan kerja, status, hubungan yang baik antara pimpinan dan karyawan, serta iklim organisasi yang terpelihara dicerminkan melalui perhatian perusahaan kepada karyawannya.

b. Job Content Factors

Job Content Factors merupakan faktor-faktor yang terkait dengan isi pekerjaan seperti tugas yang menantang, pencapaian prestasi, pengakuan, pertanggungjawaban, otonomi, kesempatan untuk berkembang, dan keikutsertaan dalam pengambilan keputusan.

c. External Environmental Factors

Seseorang mengambil keputusan untuk meninggalkan organisasi atau perusahaan diantanya karena pengaruh faktor lingkungan luar. Termasuk dalam faktor ini diantaranya ; kesempatan kerja yang terbatas, tingginya tingkat penganggurän, tanggung jawab keluarga, keberadaan keluarga besar dan komunitas lainnya, enggan untuk mengikuti perubahan pekerjaan karena faktor usia.

\section{Keadilan dan Kepuasan}

Menurut Milkovich \& Newman, konsep keadilan merupakan dasar dalam manajemen kompensasi (Howard \& Miller, 1993:882). Organisasi harus memberi perhatian bagi terciptanya keadilan individual, internal dan eksternal dari kompensasi finansial maupun non-finansial yang diberikan agar mampu menarik, mempertahankan dan memotivasi karyawan untuk mencapai kepuasan dirinya, meningkatkan kinerja dan survive-nya organisasi (Tang, Luk \& Chiu, 2000:43).

Sheppart menyatakan bahwa rasa adil terhadap kompensasi akan meningkatkan kepuasan kerja maupun kepuasan terhadap organisasi, dan pada akhirnya akan mendorong terciptanya perilaku kerja yang positif (Singh, Fujita \& Norton, 2004:230). Kepuasan kerja merupakan alat prediksi utama untuk produktivitas di masa datang. Hal ini diperkuat oleh Prickett, yang menyimpulkan bahwa kepuasan kerja mempunyai korelasi positif terhadap kinerja organisasi (Appelbaum \& Kamal, 2000:733).

\section{KERANGKA BERFIKIR}

Keadilan Kompensasi
1. Keadilan Individual $\left(\mathrm{X}_{1}\right)$
2. Keadilan Internal $\left(\mathrm{X}_{2}\right)$
3. Keadilan Ekstemal $\left(\mathrm{X}_{3}\right)$


Suhartini dan Lin Ruhana: Pengaruh Keadilan Kompensasi Terhadap Kepuasan Karyawan...

\section{HIPOTESIS PENELITIAN}

1. Secara bersama-sama keadilan individual, keadilan internal dan keadilan eksternal mempengaruhi kepuasan karyawan administratif di lingkungan Universitas Islam Indonesia, Yogyakarta.

2. Keadilan individual paling mempengaruhi kepuasan karyawan admin- । istratif di lingkungan Universitas Islam Indonesia, Yogyakarta.

3. Ada perbedaan kepuasan antara karyawan administratif struktural dan non struktural di lingkungan Universitas Islam Indonesia, Yogyakarta.

\section{D.METODE PENELITIAN}

\section{Lokasi Penelitian}

Penelitian dilaksanakan di Universitas Islam Indonesia, Yogyakarta.

\section{Variabel Penelitian}

Variabel bebas dalam penelitian ini adalah keadilan individual (X1), keadilan internal (X2) dan keadilan eksternal (X3), sedangkan variabel terikatnya adalah $\operatorname{kepuasan}(Y)$

\section{Definisi Operasional Variabel}

"Keadilan Individual (X1) adalah rasa adil yang dirasakan oleh seorang karyawan berdasarkan input.yang dimiliki. Indikator : kompensasi yang diterima sesuai dengan (a) pengetahuan, ketrampilan dan keahlian, (b) ketrampilan khusus yang dimiliki, (c) pengalaman kerja, (d) prestasi kerja, (e) loyalitas dan komitmen terhadap organisasi.

"Keadilan Internal (X2) adalah rasa adil yang dirasakan karyawan berdasarkan nilai pekerjaan yang dilaksanakannya. Indikator : Kompensasi yang diterima sesuai dengan : (a) posisi di organisasi, (b) tingkat kesulitan pekerjaan, (c) kompleksitas pekerjaan, (d) tanggung jawab pekerjaan, (e) waktu yang dibutuhkan untuk menyelesaikan pekerjaan.

"Keadilan Eksternal (X3) adalah rasa adil yang dirasakan oleh seorang karyawan berdasarkan persamaan kompensasi yang diterimanya dengan kompensasi karyawan organisasi lain untuk pekerjaan dengan nilai sama. Indikator : persamaan persepsi rasio input output dengan karyawan lain di lembaga lain untuk pekerjaan dengan nilai yang sama.

"Kepuasan $(Y)$ adalah kondisi yang menggambarkan karyawan puas dapat di lihat dari beberapa indikator : (a) Karyawan puas dengan gaji, tunjangan, jaminan keselamatan kerja yang diterima, (b) Hubungan antara pimpinan dengan karyawan baik, (c) Iklim organisasi yang cocok dan menyenangkan, (d) Diberikan tugas tugas yang menantang, mendapat pengakuan dari organisasi, diberikan otonomi, (e) Mendapat kesempatan untuk tumbuh dan berkembang, $(f)$ Diikutsertakan dalam pengambilan keputusan, (g) Tanggung jawab keluarga dapat dilaksanakan dengan baik, (h) Keluarga besar dan komunitas yang mendukung pekerjaannya, (i) Sempitnya kesempatan pekerjaan diluar.

\section{Data dan Teknik Pengumpulan Data}

Data yang dikumpulkan dalam penelitian ini meliputi dua jenis, yaitu data 
primer dan data sekunder. Sedangkan teknik pengumpulan datanya menggunakan wawancara dan angket.

\section{Uji Coba: Instrument Penelitian}

Uji validitas dari kuesioner dilakukan dengan mengkorelasikan skor butir $X$ terhadap skor total instrumen $Y$ dengan menggunakan rumus product moment dari pearson dengan perhitungan melalui koefisien penentuan (Coefficient of Determination) yang diberi notasi $r$. Pengujian dilakukan dengan membandingkan nilai product moment $(r)$ dengan nilai $r$ tab pada ( sebesar $5 \%$, dan $n=30$ adalah sebesar 0,349 . Jika $r>r$ tab maka butir pertanyaan dinyatakan valid, jika $r<r$ tab maka butir pertanyaan tidak valid dan harus digugurkan dari kuesioner (Alhusin, 2002: 341).

Pengujian yang dilakukan terhadap item-item pertanyaan dengan bantuan program SPSS for. Windows versi $\mathbf{1 2 . 0}$ for Windows. Hasil uji validitas menunjukkan bahwa terdapat 1 item pernyataan (nomor 4 dari variabel kepuasan) dinyatakan tidak valid karena $r<r$ tab $(0,326<0,349)$, sedangkan 31 item pernyataan yang lain dinyatakan valid.

Uji reliabilitas dilakukan dengan membandingkan r hasil (alpha) dengan r tab, apabila nilai Alpha Cronbanch positif dan lebih besar dari $r$ táb, kuesioner dianggap reliabel. Langkah pertama yang dilakukan adalah dengan menentukan $r$ tab, dimana diketahui sebesar 0,349 (untuk tingkat signifikansi $5 \%$ dan $n=30$ ). Hasil uji reliabilitas diketahui bahiwa besarnya Alpha Cronbach () pada masingmasing variabel menunjukkan hasil yang lebih besar dari persyaratan yang telah ditentukan sebesar 0,349.

\section{Populasi dan Sampel .}

Populasi dalam penelitian ini adalah seluruh karyawan administratif baik strukural maupun non struktural yang ada di lingkungan Universitas Islam Indonesia sebanyak 375 orang. Jumlah sampel sebanyak 191 orang, ditentukan dengan rumus : (Cooper \& Emory, 1995:215)

$$
n=\frac{(\mathrm{ZI} / 2 \alpha)^{2} \cdot \mathrm{p} \cdot \mathrm{q} \cdot \mathrm{N}}{\mathrm{E}^{2}(\mathrm{~N}-1)+(\mathrm{ZI} / 2 \alpha)^{2} \cdot \mathrm{p} \cdot \mathrm{q}}
$$

Dimana:

$\begin{array}{lll}\mathrm{E} & : & \text { deviasi sampling maksimum yang diinginkan peneliti } \\ \mathrm{Z} & : & \text { luas kurva normal standar } \\ \alpha: & : & \text { tingkat kesalahan data yang ditoleransi peneliti } \\ \mathrm{p} & \vdots & \text { nilai proporsi dari bagian populasi } \\ \mathrm{q} & : & \text { nilai proporsi selain } \mathrm{p} \\ \mathrm{N} & : & \text { jumlah populasi sampel } \\ \mathrm{n} & : & \text { jumlah sampel }\end{array}$

- Teknik pengambilan sampelnya mengguniakan cluster quota convinience sampling sebagaimana ditunjukkan dalam tabel 1. 
Tabel 1. Distribusi Sampel Menurut Bagian

\begin{tabular}{|c|c|c|c|c|c|c|c|}
\hline$\because$ & & & & & & Sampel & Sampel \\
\hline No & Unit & Struktura & Staf & Jumlah & Sampel & Struktural & Staf \\
\hline I & Univ. & 23 & 68 & 91 & 46 & 12 & 35 \\
\hline 2 & FE & 16 & 55 & 71 & 36 & 8 & 28 \\
\hline 3 & $\mathrm{FH}$ & 14 & 34 & 48 & 24 & 7 & 17 \\
\hline 4 & FTSP & 9 & 51 & 60 & 31 & 5 & 26 \\
\hline 5 & FTI & 12 & 41 & 53 & 27 & 6 & 21 \\
\hline 6 & FIAI & 7 & 19 & 26 & 13 & 4 & 10 \\
\hline 7 & FPs & 3 & 9 & 12 & 6 & 2 & 5 \\
\hline 8 & FMIPA & 4 & 3 & 7 & 4 & 2 & 2 \\
\hline 9 & FK & 3 & 4 & 7 & 4 & 2 & 2 \\
\hline Jumlah & & 91 & 284 & 375 & 191 & 46 & 145 \\
\hline
\end{tabular}

Teknik Analisis

Analisis dalam penelitian ini menggunakan analisis deskriptif dan statistik dengan menggunakan model penelitian regresi linear berganda:

$$
\begin{aligned}
& Y=a+b_{1} X_{1}+b_{2} \cdot X_{2}+b 3 . X 3 \\
& \text { Dimana: } \\
& Y \quad=\text { Kepuasan } \\
& X_{1} \quad=\text { Keadilan Individual } \\
& X_{2}=\text { Keadilan Internal } \\
& X_{3}=\text { Keadilan Eksternal } \\
& a \quad=\text { Konstanta b1, b2, b3 }
\end{aligned}
$$

Pengujian hipotesis 1,2 dan 3 digunakan uji $F$, uji $t$ dan independent sample T-tes. Proses penghitungan data baik analisis regresi, uji hipotesis 1, 2 dan 3 dilakukan dengan mengunakan program SPSS 12.0 for Windows.

Uji F digunakan untuk menguji kebenaran hipotesis I yaitu menguji pengaruh variabel-variabel bebas secara bersama-sama terhadap variabel terikat, dengan kriteria pengambilan keputusan sebagai berikut:

"Jika $\mathrm{F}$ hit $>\mathrm{F}$ tab, atau $\mathrm{p}<0,05$, maka Ho ditolak dan Ha diterima, artinya secara serentak keadilan individual, keadilan internal, dan keadilan eksternal mempunyai pengaruh yang signifikan terhadap kepuasan karyawan administratif di lingkungan Universitas Islam Indonesia, Yogyakarta.

"Jika $\mathrm{F}$ hit $<\mathrm{F}$ tab, atau $\mathrm{p}>0,05$, Ho diterima dan Ha ditolak, artinya secara serentak keadilan individual, keadilan internal, dan keadilan eksternal tidak mempunyai pengaruh yang signifikan terhadap kepuasan karyawan administratif di lingkungan Universitas Islam Indonesia, Yogyakarta:

Uji t digunakan untuk menguji kebenaran hipotesis II, yaitu untuk menguji pengaruh variabel-variabel bebas secara parsial terhadap variabel terikat, kemudian dari pengujian masing-masing variabel bebas secara parsial tersebut akan diketahui variabel mana yang paling berpengaruh terhadap variabel terikat. Kriteria pengambilan keputusan yang digunakan adalah sebagai berikut:

"Jika $t$ hit $>t$ tab, atau $t$ hit $<t$ tab, dan $p<0,05$, Ho ditolak dan Ha diterima, artinya secara parsial keadilan individual (X1), keadilan internal $(X 2)$, dan keadilan eksternal $(X 3)$ mempengaruhi kepuasan karyawan administratif di Universitas Islam Indonesia, Yogyakarta. 
primer dan data sekunder. Sedangkan teknik pëngumpulan datanya menggunakan wawancara dan angket.

\section{Uji Coba:Instrument Penelitian}

Uji validitas dari kuesioner. dilakukan dengan mengkorelasikan skor butir $X$ terhadap skor total instrumen $Y$ dengan menggunakan rumus product moment dari pearson dengan perhitungan melalui koefisien penentuan (Coefficient of Determination) yang diberi notasi $r$. Pengujian dilakukan dengan membandingkan nilai product moment $(r)$ dengan nilai $r$ tab pada ( sebesar $5 \%$, dan $n=30$ adalah sebesar 0,349 . Jika $r>r$ tab maka butir pertanyaan dinyatakan valid, jika $r<r$ tab maka butir pertanyaan tidak valid dan harus digugurkan dari kuesioner (Alhusin, 2002: 341).

Pengujian yang dilakukan terhadap item-item pertanyaan dengan bantuan program SPSS for. Windows versi 12.0 for Windows. Hasil uji validitas menunjukkan bahwa terdapat 1 item pernyataan (nomor 4 dari variabel kepuasan) dinyatakan tidak valid karena $r<r$ tab $(0,326<0,349)$, sedangkan 31 item pernyataan yang lain dinyatakan valid.

Uji reliabilitas dilakukan dengan membandingkan r hasil (alpha) dengan r tab, apabila nilai Alpha Cronbanch positif dan lebih besar dari $r$ tab, kuesioner dianggap reliabel. Langkah pertama yang dilakukan adalah dengan menentukan $r$ tab, dimana diketahui sebesar 0,349 (untuk tingkat signifikansi $5 \%$ dan $n=30$ ). Hasil uji reliabilitas diketahui bahwa besarnya Alpha Cronbach () pada masingmasing variabel menunjukkan hasil yang lebih besar dari persyaratan yang telah ditentukan sebesar 0,349 .

\section{Populasi dan Sampel}

Populasi dalam penelitian ini adalah seluruh karyawan administratif baik strukural maupun non struktural yang ada di lingkungan Universitas Islam Indonesia sebanyak 375 orang. Jumlah sampel sebanyak 191 orang, ditentukan dengan rumus : (Cooper \& Emory, 1995:215)

$$
n=\frac{(Z 1 / 2 \alpha)^{2} \cdot p \cdot q \cdot N}{E^{2}(N-1)+(Z 1 / 2 \alpha)^{2} \cdot p \cdot q}
$$

Dimana :

$\begin{array}{lll}\mathrm{E} & : & \text { deviasi sampling maksimum yang diinginkan peneliti } \\ \mathrm{Z} & : & \text { luas kurva normal standar } \\ \alpha: & \vdots & \text { tingkat kesalahan data yang ditoleransi peneliti } \\ \mathrm{p} & \vdots & \text { nilai proporsi dari bagian populasi } \\ \mathrm{q} & \vdots & \text { nilai proporsi selain } \mathrm{p} \\ \mathrm{N} & : & \text { jumlah populasi sampel } \\ \mathrm{n} & : & \text { jumlah sampel }\end{array}$

Teknik pengambilan sampelnya menggunakan cluster quota convinience sampling sebagaimana ditunjukkan daiam tabel 1. 
Suhartini dan Lin Ruhana: Pengaruh Keadilan Kompensasi Terhadap Kepuasan Karyawan...

Tabel 1. Distribusi Sampel Menurut Bagian

\begin{tabular}{|c|l|c|c|c|c|c|c|}
\hline No & Unit & Struktura & Staf & Jumlah & Sampel & Sampel & Struktural \\
\hline 1 & Univ. & 23 & 68 & 91 & 46 & 12 & Staf \\
\hline 2 & FE & 16 & 55 & 71 & 36 & 8 & 35 \\
\hline 3 & FH & 14 & 34 & 48 & 24 & 7 & 28 \\
\hline 4 & FTSP & 9 & 51 & 60 & 31 & 5 & 17 \\
\hline 5 & FTI & 12 & 41 & 53 & 27 & 6 & 26 \\
\hline 6 & FIAI & 7 & 19 & 26 & 13 & 4 & 21 \\
\hline 7 & FPS & 3 & 9 & 12 & 6 & 2 & 10 \\
\hline 8 & FMIPA & 4 & 3 & 7 & 4 & 2 & 5 \\
\hline 9 & FK & 3 & 4 & 7 & 4 & 2 & 2 \\
\hline Jumlah & & 91 & 284 & 375 & 191 & 46 & 145 \\
\hline
\end{tabular}

Teknik Analisis

Analisis dalam penelitian ini menggunakan analisis deskriptif dan statistik dengan menggunakan model penelitian regresi linear berganda:

$$
\begin{aligned}
& \mathrm{Y=a}+\mathrm{b}_{1} \mathrm{X}_{1}+\mathrm{b}_{2} \cdot \mathrm{X}_{2}+\mathrm{b} 3 . \mathrm{X}_{3} \\
& \text { Dimana: } \\
& \mathrm{Y} \quad=\text { Kepuasan } \\
& \mathrm{X}_{1} \quad=\text { Keadilan Individual } \\
& \mathrm{X}_{2}=\text { Keadilan Internal } \\
& \mathrm{X}_{3} \quad=\text { Keadilan Eksternal } \\
& \mathrm{a} \quad=\text { Konstanta b1, b2, b3 }
\end{aligned}
$$

Pengujian hipotesis 1, 2 dan 3 digunakan uji $F$, uji $t$ dan independent sample T-tes. Proses penghitungan data baik analisis regresi, uji hipotesis 1, 2 dan 3 dilakukan dengan mengunakan program SPSS 12.0 for Windows.

Uji F digunakan untuk menguji kebenaran hipotesis I yaitu menguji pengaruh variabel-variabel bebas secara bersama-sama terhadap variabel terikat, dengan kriteria pengambilan keputusan sebagai berikut:

"Jika $\mathrm{F}$ hit $>\mathrm{F}$ tab, atau $\mathrm{p}<0,05$, maka Ho ditolak dan Ha diterima, artinya secara serentak keadilan individual, keadilan internal, dan keadilan eksternal mempunyai pengaruh yang signifikan terhadap kepuasan karyawan administratif di lingkungan Universitas islam Indonesia, Yogyakarta.

"Jika $\mathrm{F}$ hit $<\mathrm{F}$ tab, atau $\mathrm{p}>0,05$, Ho diterima dan Ha ditolak, artinya secara serentak keadilan individual, keadilan internal, dan keadilan eksternal tidak mempunyai pengaruh yang signifikan terhadap kepuasan karyawan administratif di lingkungan Universitas Islam Indonesia, Yogyakarta.

Uji t digunakan untuk menguji kebenaran hipotesis $l l$, yaitu untuk menguji pengaruh variabel-variabel bebas secara parsial terhadap variabel terikat, kemudian dari pengujian masing-masing variabel bebas secara parsial tersebut akan diketahui variabel mana yang paling berpengaruh terhadap variabel terikat. Kriteria pengambilan keputusan yang digunakan adalah sebagai berikut:

"Jika $t$ hit $>\mathrm{t}$ tab, atau $t$ hit $<\mathrm{t}$ tab, dan $\mathrm{p}<0,05$, Ho ditolak dan Ha diterima, artinya secara parsial keadilan individual (X1), keadilan internal (X2), dan keadilan eksternal (X3) mempengaruhi kepuasan karyawan administratif di. Universitas Islam Indonesia, Yogyakarta. 
"Jika $t$ tab $<t$ hit, dan $p>0,05$, Ho diterima dan Ha ditolak, artinya secara parsial keadilan individual (X1), keadilan internal (X2), dan keadilan eksternal (X3) tidak mempengaruhi kepuasan karyawan administratif di Universitas Islam Indonesia, Yogyakarta.

Sedangkan independent sample T-tes digunakan untuk menguji kebenaran hipotesis III yaitu untuk menentukan apakah dua sampel independen memiliki nilai rata-rata yang berbeda. Kriteria pengambilan keputusannya adalah sebagai berikut:

"Ho diterima jika $t$ hit $>\mathrm{t}$ tab 0,05 (df 130), artinya rata-rata kepuasan antara pegawai administratif struktural dengan pegawai adminstratif non struktural adalah sama.

"Ha ditolak jika t hit $>\mathrm{t}$ tab 0,05 (df 130), artinya rata-rata kepuasan antara karyawan administratif struktural dan non struktural berbeda.

\section{E.ANALISIS DAN PEMBAHASAN}

Data penelitian dikumpulkan dengan menyebarkan 250 kuesioner langsung kepada responden. Jumlah kuesioner yang kembali dan terisi dengan lengkap sebanyak 132, cacat sebanyak 3 dan tidak kembali sebanyak 115.

\section{a.Analisis Deskriptif}

Analisis Karakteristik responden

Karakteristik responden berdasarkan jenis kelamin dibedakan menjadi dua kelompok yaitu laki-laki dan perempuan. Responden yang berjenis kelamin laki-laki sebanyak 89 orang $(67,9 \%)$ dan perempuan sebanyak 43 atau sebesar $32,1 \%$. Mayoritas responden adalah laki-laki. Dalam hal penggajian perempuan mempunyai kecenderungan lebih mudah puas dibandingkan laki-laki (Kanungo, 1992 : 98). Kecenderungan laki-laki lebih sulit dipuaskan mungkin lebih banyak disebabkan karena sebagai kepala rumah tangga, laki-laki wajib menafkahi keluarga yang memiliki jumlah kebutuhan yang tak terhitung. Sedangkan perempuan bekerja biasanya "hanya sekedar" untuk membantu menambah pendapatan keluarga, bukan sebagai tulang punggung. Seorang istri dari suami yang juga bekerja (dual income) sangat dimungkinkan ketika menerima gaji akan lebih cepat puas karena pendapatan dari bekerja bukan menjadi tujuan utamanya.

Karakteristik responden berdasarkan tingkat pendidikan terakhir dalam kuesioner ini dapat dibedakan menjadi tiga kelompok yaitu SMU/Sederajat, diploma, dan Strata 1. Karakteristik responden berdasarkan pendidikan terakhir menunjukkan bahwa responden yang pendidikan terakhir SMU/sederajat sebanyak 91 orang $(68,8 \%)$, diploma sebanyak 17 orang $(12,9 \%)$ dan Strata 1 sebanyak 24 (18,2\%). Tingkat pendidikan, ketrampilan, kemampuan dan kinerja merupakan faktor yang sangat mempengaruhi kepuasan dan harus menjadi faktor penentu tinggi rendahnya gaji karyawan. (Kanungo, 1992 : 98),

Karakteristik responden berdasarkan masa kerja dalam kuesioner ini dapat dibedakan menjadi lima kelompok, yaitu bahwa responden yang masa kerjanya 5-10 tahun sebanyak 20 (15,2\%), 11-15 tahun sebanyak 34 orang (25,8\%), 16- 
20 tahun sebanyak 28 orang (21.1\%) , 21-25 tahun sebanyak 29 orang (22\%) dan diatas 25 tahun sebanyak 21 orang (15,9\%). Ada kecenderungan pegawai yang tua merasa puas daripada pegawai yang berumur relatif muda. Hal ini diasumsikan bahwa pegawai yang tua lebih berpengalaman menyesuaikan diri dengan lingkungan pekerjaan. Sedangkan pegawai usia muda biasanya mempunyai kesenjangan antara harapan dengan realita kerja sehingga dapat menyebabkan mereka menjadi tidak puas (Mangkunegara, 2001 : 118). Hasil penelitian menunjukkan bahwa pada beberapa masyarakat dengan budaya tertentu menganggap bahwa karyawan akan merasa puas terhadap gaji apabila gaji tersebut mencerminkan umur dan senioritas (Kanungo, 1992: 98).

Karakteristik responden berdasarkan jabatan struktural dalam kuesioner ini dapat dibedakan menjadi dua yaitu pegawai administratif struktural dan pegawai administratif non struktural. Karakteristik ini menunjukkan bahwa responden yang mempunyai jabatan struktural dalam hal ini kepala bagian dan kepala urusan sebanyak 61 orang $(46,2 \%)$ dan non struktural sebanyak 71 orang $(53,8 \%)$. Secara struktural pegawai-pegawai yang menduduki tingkat pekerjaan yang lebih tinggi cenderung lebih puas daripada pegawai yang menduduki tingkat pekerjaan yang lebih rendah. Pegawai-pegawai yang tingkat pekerjaannya lebih tinggi menunjukkan kemampuan kerja yang baik dan aktif dalam mengemukakan ideide serta kreatif dalam bekerja (Mangkunegara, 2001 : 119). Karyawan yang menduduki posisi jabatan yang lebih tinggi di struktur organisasi, mengerjakan pekerjaan dengan tingkat kesulitan, kompleksitas, tanggujawab yang lebih tinggi, dan waktu pengerjaan yang lebih sempit, pasti akan memiliki harapan atas imbalan yang semakin tinggi pula. Apabila imbalan yang mereka terima gagal mencerminkan input mereka, maka karyawan akan merasakan ketidakpuasan terhadap upah yang mereka terima. (Kanungo, 1992: 99)

Analisis Variabel Keadilan Kompensasi dan Kepuasan

Dalam analisis ini, terlebih dahulu dilakukan penghitungan interval kelas didasarkan pada selisih nilai tertinggi dan nilai terendah dibagi dengan jumlah kelompok/kelas yang diinginkan (Hakim, 2001:71). interval $=\mathrm{H}-\mathrm{L}$

$K$

Dimana: $\mathrm{H}=$ nilai tertinggi

$L=$ nilai terendah

$\mathrm{K}=$ jumlah kelas

Tabel 2. Kategori Jawaban Jesponden Berdasarkan Interval

\begin{tabular}{|l|c|}
\hline \multicolumn{1}{|c|}{ Kategori Jawaban } & Bobot \\
\hline Sangat tidak sesuai/Adi//Tinggi & $1-2$ \\
\hline Tidak sesuai/Adil/Tinggi & $2,1-3,1$ \\
\hline Sesuai/Adil/Tinggi & $3,2-4,2$ \\
\hline Sangat sesuai/Adil/Tinggi & $4,3-5$ \\
\hline
\end{tabular}


Tabel 3.

Distribusi Skor Rata-rata Jawaban Responden untuk Variabel Keadilan Individual (X1)

\begin{tabular}{|c|c|}
\hline Inti Pernyataan & Skor \\
\hline Kesesuaian gaji dengan tingkat pendidikan. & 3,37 \\
\hline Kemampuan khusus yang dimiliki karyawan dihargai oleh institusi. & 3,56 \\
\hline Pengalaman kerja mempengaruhi tinggi rendahnya gaji. & 3,27 \\
\hline Semakin berkinerja pendapatan semakin tinggi. & 3,32 \\
\hline Kenaikan gaji berkala tercemin dalam lamanya pengabdian. & 3,9 \\
\hline Institusi menghargai loyalitas karyawan. & 3,98 \\
\hline Tidak ada peraturan yang menghargai laki-laki lebih tinggi dại & 3,8 \\
\hline Pemberian kompensasi tidak berdasarkan pada asal-usul karyawannya & 3,92 \\
\hline Rata-rata & $3 . \overline{6}$ \\
\hline
\end{tabular}

Tabel 3 menunjukkan bahwa keadilan individual memiliki rata-rata sebesar 3.6 , termasuk dalam kategorikan adil. Artinya, bahwa pegawai administratifyang bekerja di lingkungan Universitas Islam Indonesia, Yogyakarta merasakan adanya kesesuaian antara input yang karyawan bawa berupa pendidikan, kemampuan, pengalaman kerja, serta loyalitas mereka dengan imbalan yang diterima.

Tabel'4.

Distribusi Skor Rata-rata Jawaban Responden untuk Variabel Keadilan Internal (X2)

\begin{tabular}{|c|c|}
\hline Inti Pertanyaan & Skor \\
\hline Kesesuaian gaji dengan posisi di struktur organisasi. & 3,45 \\
\hline Kesesuaian gaji dengan tingkat kesulitan pekerjaan. & 2,88 \\
\hline Kesesuaian gaji tingkat kompleksitas pekerjaan. & 2,92 \\
\hline Kesesuaian gaji dengan tanggungjawab pekerjaan. & 3,35 \\
\hline Kesesuaian gaji dengan waktu yang diberikan untuk menyelesaikan & 2,64 \\
\hline Rata-rata & 3.05 \\
\hline
\end{tabular}

Tabel 4 menunjukkan bahwa keadilan internal memiliki rata-rata 3,05 termasuk dalam kategori tidak adil. Responden merasa mendapat perlakuan tidak adil secara internal artinya karyawan merasa terdapat kesenjangan antara kompensasi yang mereka terima dengan nilai pekerjaan yang mereka laksanakan. Kesenjangan ini dapat disebabkan beberapa hal diantaranyả harapan karyawan yang berlebih terhadap institusi, institusi yang belum melakukan penilaian pekerjaan secara detail, ataupun kurangnya komunikasi mengenai program kompensasi yang diterapkan. 
Suhartini dan Lin Ruhana: Pengaruh Keadilan Kompensasi Terhadap Kepuasan Karyawan...

Tabel 5

Distribusi Skor Rata-rata Jawaban Responden terhadap Pertanyaan Variabel Keadilan Eksternal (X3)

\begin{tabular}{|c|c|}
\hline \multicolumn{1}{|c|}{ Inti Pertanyaan } & Skor \\
\hline Karyawan sering bertanya dengan teman seprofesi tentang jumlah gaji & 2,83 \\
\hline Gaji yang diterima sesuai dengan orang lain yang pernah menduduki & 3,16 \\
\hline Rata-rata & 3.00 \\
\hline
\end{tabular}

Tabel 5 menunjukkan bahwa keadilan eksternal memiliki rata-rata 3,00 , termasuk dalam kategori tidak adil. Ketidakadilan yang dirasakan secara eksternal oleh karyawan bisa disebabkan karena karyawan enggan bertanya kepada teman seprofesi, karyawan juga enggan untuk membandingkan gaji yang mereka terima dengan orang lain yang pernah menduduki posisi yang sama. Akibatnya, ketidakadilan kompensasi dari sudut eksternal yang dirasakan karyawan hanya perasaan sesaat, mungkin karyawan belum mampu mempertimbangkan dan membandingkan secara matang dengan pekerjaan senilai. Oleh karena itu UII perlu melakukan survei gaji secara berkala untuk mengetahui posisi kompensassi yang diberikan pada pekerjaan-pekerjaan senilai di institusi lainnya.

Tabel 6.

: Distribusi Skor Rata-rata Jawaban Responden terhadap Pertanyaan Variabel Kepuasan $(Y)$

\begin{tabular}{|l|c|}
\hline \multicolumn{1}{|c|}{ Inti Pertanyaan } & Skor \\
\hline Dengan bekerja di UII, kebutuhan hidup menjadi terpenuhi. & 3,35 \\
\hline Hubungan kerja saya, teman dan pimpinan sangat menyenangkan. & 3,79 \\
\hline Lingkungan kerja mendukung perkembangan dan pribadi karyawan. & 3,8 \\
\hline Peraturan pemutusan kerja sesuai dengan Undang-undang yang berlaku. & 2,82 \\
\hline Tugas yang diberikan membuat karyawan semakin bersemangat untuk & 3,87 \\
\hline Mampu menyelesaikan tugas sesuai dengan ketentuan. & 3,97 \\
\hline Kinerja diakui oleh semua pihak. & 3,7 \\
\hline Tanggungjawab yang diemban sesuai dengan kemampuan. & 3,9 \\
\hline Diberi hak untuk menyelesaikan pekerjaan sesuai dengan idenya. & 3,23 \\
\hline $\begin{array}{l}\text { Diberi pelatihan setiap ada perkembangan baru yang sesuai dengan } \\
\text { tugasnya. }\end{array}$ & 3,3 \\
\hline $\begin{array}{l}\text { Ikut dilibatkan dalam pengambilan keputusan sesuai dengan diri dan } \\
\text { tugas yang harus dikerjakan. }\end{array}$ & 3,42 \\
\hline Keluarga sangat mendukung bekerja di UII. & 4,29 \\
\hline UII memberikan fasilitas anak karyawan untuk kuliah di UII. & 4,22 \\
\hline Suami dan isteri sama-sama bekerja di UII & 3,34 \\
\hline Yogyakarta adalah kota pilihan untuk bekerja dan membina keluarga. & 4,1 \\
\hline $\begin{array}{l}\text { Sulit mencarai .pekerjaan baru melihat ketrampilan dan usia seperti } \\
\text { sekarang. }\end{array}$ & 3,52 \\
\hline \multicolumn{1}{|c}{ Rata-rata } & 3.66 \\
\hline
\end{tabular}


Tabel 6 menunjukkan bahwa kepuasan karyawan terhadap kompensasi yang diterima memiliki rata-rata 3,66, termasuk dalam kategori puas. Responden telah merasakan kepuasan terhadap kompensasi yang diterimanya baik yang berasal dari job context factors, job content factors, dan ekstemal enivironmental factors: Meskipun begitu, adanya rata-rata skor jawaban yang sangat rendah $(2,82)$ untuk item pertanyaan mengenai pemutusan hubungan kerja (PHK), haruslah menjadi "warning" bagi UIl untuk lebih memberikan kepuasan terkait dengan penilaian kinerjà, aturan PHK maupun pelaksanaannya.

b.Analisis Statistik

Analisis Regresi Linier Berganda

Tabel 7. Hasil Rekapitulasi Regresi Linier Berganda

\begin{tabular}{|c|c|c|c|c|c|}
\hline No & Variabel bebas & $\mathrm{b}$ & $\mathrm{t}$ hitung & $\mathrm{t}$ tabel & $\therefore$ Keterangan \\
\hline 1 & $\mathrm{X}_{1}$ & 0,355 & 5,599 & 1,66 & Signifikan \\
\hline 2 & $\mathrm{X}_{2}$ & 0,12 & 2,568 & 1,66 & Signifikan \\
\hline 3 & $\mathrm{X}_{3}$ & $-0,073$ & $-1,381$ & 1,66 & Tidak Signifikan \\
\hline
\end{tabular}

Hasil statistik dengan menggunakan bantuan SPSS Ver.12.00 menunjukkan persamaan regresi $Y=2,225+0,355 \times 1+0,120 \times 2-0,073 \times 3$.

\section{Uji Hipotesis Pertama}

Tabel 7 menunjukkan bahwa $F$ hit sebesar 19,935> dari F tab sebesar 2,675 . Hipotesis pertama terbukti kebenarannya artinya secara bersama-sama keadilan individual (X1), keadilan internal $(X 2)$, dan keadilan eksternal $(X 3)$ memiliki pengaruh yang signifikan terhadap kepuasan pegawai adiminstratif di lingkungan Universitas Islam Indonesia, Yogyakarta.

Besarnya koefisien determinasi $\left(R^{2}\right)$ yaitu sebesar 0,302 artinya bahwa variabel keadilan kompensasi mempunyai pengaruh terhadap variabel kepuasan karyawan sebesar $30,2 \%$ sedangkan sisanya dipengaruhi oleh variabel lain selain variabel keadilan kompensasi. Variabel lain tersebut seperti proses komunikasi dan pengambilan keputusan (Kanungo, 1992: 13). Komunikasi yàng efektif dapat mengurangi kesenjangan, oleh karenanya apabila terdapat kebijakan baru yang dikeluarkan oleh pimpinan hendaknya dikomunikasikan kepada karyawan. Selain itu, proses pelibatan karyawan dalam pengambilan keputusan terkait dengan kompensasi merupakan bagaian penting, karena karyawan akan merasa lebih dihargai. 


\section{Uji Hipotetsis kedua}

Tabel 8.

Perbandingan Nilai b, thitung, t tabel pada Masing-masing Variabel Bebas pada Taraf Nyata $5 \%$.

\begin{tabular}{|c|c|c|c|c|c|}
\hline No & Variabel bebas & $\mathrm{b}$ & $\mathrm{t}$ hitung & $\mathrm{t}$ tabel & Keterangan \\
\hline $\mathrm{I}$ & $\mathrm{X}_{1}$ & 0,355 & 5,599 & 1,66 & Signifikan \\
\hline 2 & $\ddot{\mathrm{X}_{2}}$ & 0,120 & 2,568 & 1,66 & Signifikan \\
\hline 3 & $\mathrm{X}_{3}$ & $-0,073$ & $-1,381$ & 1,66 & Tidak Signifikan \\
\hline
\end{tabular}

Tabel 8 menunjukkan bahwa :

1.Keadilan individual mempunyai pengaruh signifikan terhadap variabel kepuasan. Diantara ketiga variabel bebas yang mempunyai angka koefisien beta paling besar adalah koefisien beta dari variabel keadilan individual (X1), sehingga dapat ditarik kesimpulan bahwa keadilan individual paling berpengaruh terhadap kepuasan. Adil individual dirasakan oleh karyawan adminstratif yang bekerja di lingkungan Universitas Islam Indonesia, Yogyakarta, karena input karyawan seperti pendidikan, kemampuan, pengalaman kerja, penghargaan, dirasa telah dihargai sesuai dengan kompensasi yang mereka terima. Dengan demikian hipotesis yang menyatakan keadilan individual paling mempengaruhi kepuasan pegawai administratif di lingkungan Universitas Islam Indonesia, Yogyakarta terbukti dan dapat diterima.

Diperolehnya data bahwa keadilan individual merupakan variabel yang paling mempengaruhi kepuasan karyawan, harus mendorong Ull untuk senantiasa melakukan penilaian prestasi keja secara berkesinambungan. Penilaian kinerja dapat membantu pihak manajemen mengantisipasi dan mencegah ketidakpuasan karyawan. Selama ini UIl telah melakukan kegiatan penilaian kinerja untuk karyawannya. Penilaian kinerja dilakukan oleh masing-masing unit dan ditujukan kepada seluruh karyawan baik struktural maupun non struktural. Penilaian kinerja diUll disebut dengan DP3 (Daftar Penilaian Pelaksana Pekerjaan). Materi penilaian meliputi meliputi kehadiran, kemampuan, kecakapan, kecekatan, keahlian, kepribadian, keramahan, kesopanan, penampilan dan kreativitas dalam bekerja.

Sistem penilaian dan hasil penilaian kinerja hendaknya disusun dengan melibatkan semua pihak terkait dan dikomunikasikan secara jelas agar mampu mempertinggi rasa adil individual dan pada akhirnya mampu mempertinggi kepuasan kerja. Sheppart menyatakan bahwa rasa adil terhadap kompensasi akan meningkatkan kepuasan kerja maupun kepuasan terhadap organisasi, dan pada akhirnya akan mendorong terciptanya perilaku kerja yang positif (Singh, Fujita \& Norton, 2004:230).

2.Keadilan internal memberikan pengaruh yang signifikan terhadap variabel kepuasan. Karyawan merasakan adil secara internal hal ini dapat dilihat dari koefisien beta bernilai positif. Karyawan merasakan adil karena gaji yang karyawan terima sesuai dengan tingkat kesulitan pekerjaan, kompleksitas pekerjaan, tanggungjawab pekerjaan dan waktu untuk menyelesaikan pekerjaan. Ull dapat lebih meningkatkan rasa adil secara internal ini dengan melakukan penilaian pekerjaan (job evaluation) secara periodik, khususnya apabila terjadi perubahan 
struktur dan metode kerja. Perubahan tersebut secara langsung akan mempengaruhi nilai suatu pekerjaan (value of job).

3.Keadilan eksternal memberikan pengaruh yang tidak signifikan terhadap variabel kepuasan. Masalah keadilan eksternal yang kurang begitu diperhatikan oleh karyawan. Berdasarkan hasil wawancara dengan responiden peneliti dapat disimpúlkan bahwa bagi sebagian karyawan untuk menanyakan teritang gaji atau kompensasi kepada teman seprofesi yang bekerja di institusi lain adalah hal yang kurang etis; sehingga tidak perlu dipertanyakan. Sebagian karyawan juga membandingkan hanya dari segi besarnya nilai nominal gaji saja, tanpa mempertimbangkan faktor lain seperti mereka membandingkan fasililitas yang diberikan dari institusi, ruang kerja, lingkungan kerja dan faktor lain. Ketidakadilan secara eksternal yang dirasakan oleh karyawan terhadap institusi lain yang sejenis bisa juga dikarenakan karyawan belum mampu membandingkan secara matang. Hal ini dapat disebabkan karena karyawan membandingkan hanya berdasarkan pada rasa keingintahuan saja, sehingga yang terjadi adalah penilaian yang hanya berdasarkan pada pertimbangan tertentu dan sesaat.

\section{Uji Hipotesis Ketiga}

Tabel 9. Perbedaan Kepuasan Pegawai Administratif Struktural dan Non Struktural dilihat dari Nilai t hitung

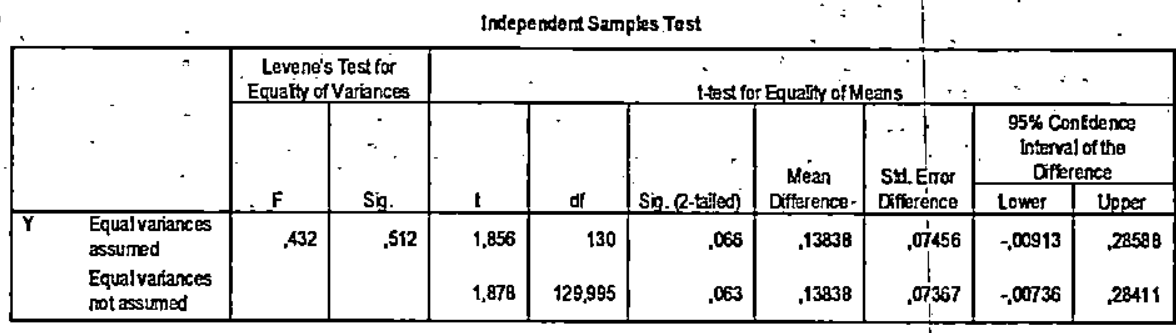

Tabel 9 menunjukkan bahwa harga $F=0,432$ dengan tingkat signifikansi $=0,512$. Probabilitas $0,512>0,05$, maka Ho yang menyatakan "bahwa kedua varians kepuasan pegawai administratif struktural dan non struktural sama" diterima. Mengingat kedua varians sama, maka dalam pengujian t akan lebih tepat menggunakan asumsi Equal Variance assumed.

Tabel 9 menunjukkan bahwa harga thit sebesar $1,856>t$ tab sebesar 1,66. maka Ho yang menyatakan "rata-rata kepuasan pegawai administrațif struktural dan non struktural sama", diterima. Dengan demikian hipotesis ketiga yang menyatakan ada perbedaan kepuasan antara pegawai administratif struktural dan pegawai adminstratif non struktural di lingkungan Universitas Islam Indonesia, Yogyakarta, tidak terbukti dan tidak dapat diterima.

1.Hipotesis pertama yang menyatakan bahwa "secara bersama-sama keadilan indlvidual, keadilan internal dan keadilan eksternal mempengaruhi kepuasan karyawan administratif di lingkungan Universitas Islam Indonesia, Yogyakarta", terbukti. Hal ini dapat dilihat dari besarnya $\mathrm{F}$ hit $(19,935)>\mathrm{F}$ tab 
Suhartini dan Lin Ruhana: Pengaruh Keadilan Kompensasi Terhadap Kepuasan Karyäwan...

2,675 . Besarnya koefisien determinasi $\left(R^{2}\right)$ yaitu sebesar 0,302 yang mempunyai áti bahwa variabel keadilan individual, keadilan internal, dan keadilan eksternal mempunyai pengaruh sebesar $30,2 \%$ terhadap képuasan pegawai. Sisanya dipengaruhi oleh variabel lain, yaitu proses komunikasi dan pengambilan. keputusan.

2.Hipotesis kedua yang menyatakan bahwa "keadilan individual paling mempengaruhi kepuasan pegawai administratif di lingkungan Universitas Islam Indonesia, Yogyakarta", terbukti. Hal ini terlihat dari hasil perhitungan uji t yaitu besarnya thit untuk variabel keadilan individual $5,599>$ keadilan internal 2;568 > keadilan eksternal $-1,381$.

3. Hipotesis ketiga menyatakan bahwa "ada perbedaan kepuasan antara pegawai administratif struktural dan pegawai adminstratif non struktural di lingkungan Universitas Islam Indonesia, Yogyakarta " tidak terbukti. Hal.ini terlihat dari hasil pengujian independen sampel t-tes yaitu dengan tahap pertama uji $F$ yang menggunakan asumsi kedua varians kepuasan pegawai administratif struktural dan non struktural sama. Oleh karena kedua varians sama, maka dalam uji $t$ menggunakan asumsi yang sama juga yaitu kedua varian sama. Hasil perhitungan dengan uji $t$ yaitu harga $t$ hit sebesar $1,856>t$ tab sebesar 1,66. Dengan demikian $t$ hit $>t$ tab, artinya bahwa rata-rata kepuasan pegawai administratif yang bekerja di lingkungan Universitas Islam Indonesia, Yogyakarta adalah sama (tidak berbeda).

1. Ull perlu memberikan perhatian yang besar pada peningkatan kualitas penilaian kinerja karyawan dan mengaitkan secara signifikan terhadap kompensasi yang akan diterima.

2. . UII perlu melakukan survei gaji secara berkala untuk meningkatkan rasa adil eksternal.

3. UIl perlu melakukan survei kepuasan secara periodik untuk menemukan item kompensasi yang dibutuhkan oleh karyawan sehingga kompensasi yang diberikan akan mampu meningkatkan motivasi kinerja karyawan.

4. Bagi peneliti selanjutnya, disarankan untuk meneliti variabel lain yang mempengaruhi kepuasan karyawan yaitu variabel komunikasi dan pengambilan keputusaṇ. 
Alhusin, S. (2002). Aplikasi Statistik Praktis dengan SPS\$.10. Yogyakarta: J\&J Learning.

Appelbaum, Steven H.\& Kamal, Rammie (2000). "An Analysis of the Utilization and Effectiveness of Non-Financial Incentives in Small Business", The Journal of Management Development, Bradford: Vol 19, iss 9/10, p 733.

Budiyuwono, Nugroho. (1996). Pengantar Statistik ekonomi dan Perusahaan, Jilid II. Yogyakarta: UPP AMP YKPN.

Cooper R Donald \& Emory C William. 1995. Business Research Methods, Richard Irwin Inc, Chicago

Davis, Keith. (1985), Human Behavior at Work: "Organizational Behaviour". New Delhi: tata McGraw-Hill Publishing Company.

Dessler, Garry. (2004). Manajemen Sumber Daya Manúsia, Jilid 1, Edisi kesembilan, alih bahasa Eli Tanya. Jakarta: PT Indeks Kelompok Gramedia

Furtwengler, Dale. (2000). Penilaian kinerja. Yogyakarta: Andi.

Hadi, Sutrisno. (1981). Statistik. Jilid II. Yogyakarta: Yayasan Penerbit Fakultas Psikologi UGM

Hakim, Abdul. (2001). Statistik Deskriptif untuk Ekonomi dan Bisnis.Yogyakarta. Ekonisia.

Hanafi M. Mamduh . (1997). Manajemen. Yogyakarta : UPP AMP YKPN.

Howard, Larry W \& Miller, Janis L. (1993). "Fair Pay for Fair Pay : Estimating Pay Equity in Proffesional baseball with Data Envelopment Analysis". Academy of Management Journal. Briarcliff Manor: Vol.36, Iss4, p882.

Kanungo, R.N. and Mendonca. (1992). Compensation: Effective Reward Management. Canada: Butherworths. Hill.

Lawler. (1971). Pay and Organizational Effectivness. New York: McGraw-

Mangkunegara, A, Prabu. (2001). Manajemen Sumber Daya manusia Perusahaan. Bandung. PT Rosdakarya.

Nugroho, Agung B. (2005). Strategi Jitu Memilih Metode Statistik Penelitian dengan SPSS. Yogyakarta: Andi.

Nugroho, Setyo W. (2002). Pengaruh persepsi Rasa Keadilan Terhadap kepuasan Kerja pada Karyawan Administrasi Fakultas Ekonomi Universitas islam Indonesia, Yogyakarta. Skripsi Sarjana (Tidak dipublikasikan). Yogyakarta: Fakultas Ekonomi Ull. 
Suhartini dan Lin Ruhana: Pengaruh Keadilan Kompensasi Terhadap Kepuasan Karyawan...

Prabandini, K, Anjar. (2003). Analisis Pengaruh Stressor tarhadap Kepuasan Kerja Karyawan (Studi Kasus pada SKH Radar Jogja). Skripsi Sarjana (Tidak dipublikasikan). Yogyakarta: Fakultas Ekonomi UI!.

Pramono, Djoko. (2004). Pengaruh Persepsi Kompensasi Yang Adil Terhadap Produktivitas Kerja pada Karyawan Perusahaan Otobus Jaya Putra Delangu, Klaten. Skripsi Sarjana (Tidak dipublikasikan). Yogyakarta: Fakultas Ekonomi UII.

Singarimbun Masri dan Sofian Efendi. (1989). Metode Penelitian Survei. Edisi Revisi. Jakarta: LP3S.

Singh, Douglas, Frank Fujita, \& Steven D. Norton. (2004). "Determinants of Satisfaction with Pay among Nursing Home Administrators". Juornal of American Academy of Business Cambridge, Hollywood:Vol 5, Iss 1/2, p 230.

Simamora, Hanry. (2001). Manajemen Sumber Daya Manusia. Edisi kedua. Yoyakarta: STIE YKPN.

Stephen P Robbin. (1996). Perilaku Organisasi: Konsep, Kontraversi, Aplikasi. Jilid 2. Alih bahasa Hadyana Pujaatmaka. Jakarta: PT. Prehallindo.

Tang, Thomas Li Pang, Vivenne Wai-Mei Luk, Randy K. Chiu. (2000). "Pay Differential in the People's Republic of China: An Examination of Internal Equity and External Competitiveness", Compensation and Benefits Review. Saranac Lake:Vol 32, Iss 3, p 43.

Tim Mitra Bestari. (2005). Manajemen Sumber Daya Manusia. Yogyakarta: UPFE Universitas Muhammadiyah Yogyakarta.

Timothy J Keaveny, Edward J Inderrieden. (2000). "Gender differences in pay satisfaction and pay expectations". Journal of Managerial Issues. Vol. 12, Iss. 3; pg. 363,17 pgs.

Tohardi, Ahmad. (2002). Pemahaman Praktis Manajemen Sumber Daya manusia. Bandung: Mandar Maju.

Umar, Hussein. (1998). Riset Sumber Daya Manusia Dalam Organisasi. Edisi Revisi. Jakarta: Gramedia Pustaka Utama

Wallace, Marc J., dan Charles H. Fay. (1988). Compensation Theory and Practice. Boston: PWS-Kent.

Wexley.K.N. dan Yulk. G.A. (1977).Organizational Behaviour and Personel Psychology. Ricarrd D. Irwin. 